\title{
PERTAMBAHAN BERAT BADAN IBU HAMIL BERHUBUNGAN DENGAN ANGKA KEJADIAN PREEKLAMSIA
}

\author{
Ratih Purnama ${ }^{1 *}$, Aryati Wardiah², Rahma Ellya ${ }^{3}$ \\ 1,2,3,Prodi Program Studi IImu Keperawatan Universitas Malahayati \\ *Korespondensi email ratihpurnama4695@gmail.com
}

\section{ABSTRACT THE RELATIONSHIP BETWEEN PREGNANT WOMEN WEIGHT GETTING AND PREEKLAMSIA}

Background: High gestational weight at 16-19 weeks is associated with a significant increase in the risk of preeclampsia. Maternal Mortality Rate in Lampung Province occurred 179 cases, in Bandar Lampung City, by comparing 3 Puskesmas with the highest incidence of preeclampsia, namely Korpri Health Center with 9 (11.39\%) incidence of 79 pregnant women, Sukaraja Community Health Center $7(10.60 \%)$ incidence of 66 pregnant women, and Pasar Simpur 7 Health Center (11.11\%) incidence of 63 pregnant women.

Purpose: To determine the relationship between the weight of pregnant women and the incidence of preeclampsia in the work area of the Korpri Health Center in Bandar Lampung City in 2019.

Methods: This type of research uses quantitative, with anresearch design analytic survey, and aapproach cross sectional, the population and sample are pregnant women at the Korpri Health Center in 2019, simple random sampling technique. Univariate and bivariate data analysis used the Chi- square test

Results: The weight gain of 88 pregnant women, with the normal weight category of 61 respondents $(45.8 \%)$. The incidence of preeclampsia from 88 pregnant women, with the category of not experiencing preeclampsia, was 60 respondents $(68.2 \%)$. The results of statistical tests using thetest chi square obtained $p$ value $=0.000(<0.05)$.

Conclusion: There is a relationship between the weight gain of pregnant women and the incidence of preeclampsia in the Work Area of the Bandar Lampung City Korpri Health Center in 2019. All prospective mothers are advised to plan to get pregnant at a productive age, because in that age range the work of the reproductive organs has been maximized and if the mother plans Subsequent pregnancies, then to pay attention to body weight during pregnancy with a normal increase range of $11.35-15.89 \mathrm{Kg}$.

Suggestion Health workers can provide education to pregnant women to detect preeclampsia early and provide maximum service to preeclampsia sufferers to prevent complications.

Keywords : Weight Gain, Preeclampsia, Pregnant Women.

\section{ABSTRAK}

Pendahuluan: Berat badan kehamilan tinggi pada 16-19 minggu dikaitkan dengan peningkatan yang berarti dalam risiko preeklamsia. Angka Kematian lbu di Provinsi Lampung terjadi 179 kasus, Di Kota Bandar Lampung, dengan membandingkan 3 Puskesmas yang memiliki angka kejadian preeklamsia tertinggi, yaitu Puskesmas Korpri sebanyak 9 (11,39\%) kejadian dari 79 ibu hamil, Puskesmas Sukaraja 7 (10,60\%) kejadian dari 66 ibu hamil, dan Puskesmas Pasar Simpur 7 (11,11\%) kejadian dari 63 ibu hamil.

Tujuan: Diketahui hubungan pertamahan berat badan ibu hamil dengan angka kejadian preeklamsia di wilayah kerja Puskesmas Korpri Kota Bandar Lampung Tahun 2019.

Metode: Jenis penelitian menggunakan kuantitatif, dengan rancangan penelitian survey analitik, dan pendekatan cross sectional, populasi dan sampel adalah ibu hamil di Puskesmas Korpri tahun 2019, teknik sampling simpel random sampling. Analisis data univariat dan bivariat mengguankan uji uji chisquare

Hasil : Pertambahan berat badan dari 88 ibu hamil, dengan kategori berat badan normal 61 responden $(45,8 \%)$. Kejadian preeklamsia dari 88 ibu hamil, dengan kategori tidak mengalami preeklamsia 60 responden $(68,2 \%)$. Hasil uji statistik menggunakan uji chi square didapat nilai $p$-value $=0.000(<0.05)$.

Simpulan : Ada hubungan pertambahan berat badan ibu hamil dengan angka kejadian preeklamsia di Wilayah Kerja Puskesmas Korpri Kota Bandar Lampung Tahun 2019. Kepada seluruh calon ibu disarankan untuk merencanakan hamil di usia produktif, karena dalam rentang usia tersebut kerja organ reproduksi telah maksimal dan bila ibu merencanakan kehamilan berikutnya, selanjutnya untk memperhatikan berat badan selama kehamilan dengan batasan kenaikan normal 11,35-15,89 Kg. 


\section{JKM (Jurnal Kebidanan Malahayati),Vol 7,No.2.April 2021, ISSN (Print) 2476-8944 ISSN (Online) 2579-762X, Hal 324-331}

Saran: Kepada tenaga kesehatan dapat memberikan memberikan edukasi kepada ibu hamil guna mendeteksi dini adanya preeklampsia dan memberikan pelayanan maksimal kepada penderita preeklampsia guna mencegah terjadinya komplikasi

Kata Kunci : Pertambahan Berat Badan, Preeklamsia, Ibu Hamil.

\section{PENDAHULUAN}

Angka kematian ibu berkisar 305 per 100.000 menurut Survei Angka Sensus(Supas) tahun 2015. Dari 14.640 total kematian ibu yang dilaporkan hanya 4.999 , berarti ada 9.641 yang tidak dilaporkan ke pusat. Dari data tersebut, ada 83.447 kematian ibu di desa maupun kelurahan, sementara di Puskesmas ada 9.825 kematian ibu, dan 2.868 kematian ibu di rumah sakit. penyebab kematian ibu. Akibat gangguan hipertensi sebanyak $33,07 \%$, perdarahan obstetrik $27.03 \%$, komplikasi non obstetric $15.7 \%$, komplikasi obstetric lainnya $12.04 \%$ infeksi pada kehamilan $6.06 \%$ dan penyebab lainnya $4.81 \%$. Sementara penyebab kematian neonatal tertinggi disebabkan oleh komplikasi kejadian intraparum tercatat 283\%, akibat gangguan respiratori dan kardiovaskular $21.3 \%$, BBLR dan premature $19 \%$, kelhiran kongenital $14,8 \%$, akibat tetanus neonatorum $1,2 \%$, infeksi $7.3 \%$ dan akibat lainnya $8.2 \%$ (Kemenkes RI, 2019)

Angka kejadian preeklamsia didunia sebesar 3-10\% dan di Indonesia sebersar 9,8-25,5\%. Berdasarkan Survei Demografi dan Kesehatan Indonesia (SKDI) Tahun 2018, AKI sebesar 359 per 100.000 kelahiran hidup. Angka kejadian ini meningkat tajamdari tahun 2007 yang sudah mencapai 228. Angka kematian ibu di Indonesia jauh lebih tinggi dibandingkan dengan negara lain ASEAN seperti di Singapura hanya 6 per 100.000 kelahiran hidup. Brunei 33 per 100.000 kelahiran hidup. Dan filipina 112 per 100.000 kelahiran hidup (Kemenkes RI, 2018). Penyebab kematian ibu sangatlah beragam, akan tetapi kematian ibu di Indonesia masih di dominan oleh tiga penyebab utama yaitu perdarahan, hipertesi dalam kehamilan(HDK) dan infeksi (Kemenkes RI, 2018).

Berdasarkan penelitian yang dilakukan oleh P. Himes (2018) yang berjudul Early-pregnancy weight gain and the risk of preeclampsia menyatakan kejadian preeklamsia yang diketahui adalah $3,5 \%, 4,7 \%, 6,2 \%, 5,6 \%$, dan $7,0 \%$ untuk berat badan normal, kelebihan berat badan, obesitas kelas 1, obesitas kelas 2, dan obesitas kelas 3, masing-masing. Sekitar 95\% - 16\% dari kehamilan preeklamsia disampaikan sebelum 34 minggu. Berat badan kehamilan tinggi pada 16-19 minggu dikaitkan dengan peningkatan yang berarti dalam risiko preeklamsia antara perempuan dengan hamil yang normal BMI dan obesitas kelas 2 atau obesitas kelas 3 dibandingkan dengan kelompok referensi dari keuntungan awal rendah (1 SD). Ketika wanita dengan obesitas kelas 2 dan 3 digabungkan > berat badan 1 SD di 16- 19 minggu dikaitkan dengan $3,0(95 \% \mathrm{Cl} 0,01,58)$ kasus kelebihan per 100 kelahiran dibandingkan dengan rujukan tersebut (P. Himes, 2018).

Kejadian peningkatan BB pada ibu hamil yang tidak terkontrol atau berlebih memberikan resiko kehamilan yang tinggi yaitu diabetes gestasional, preeklamsia, kehamilan pascamatur, bedah caesar darurat,bedah ceasar efektif, perdarahan pascapartum, infeksi panggul, infeksi saluran kemih, infeksi luka, makrosomia, lahir mati. Preeklamsia merupakan penyulit kehamilan yang sangat di hindari baik pada saat kehamilan, persalinan, maupun nifas. Gejala yang timbul pada saat preeklamsia adalah edema, hipertensi, proteinuria, dan umur. (Pratamaningtyas 2019).

Tahun 2017 Angka Kematian Ibu di Provinsi Lampung terjadi 179 kasus, kematian ibu dengan masih seputar eklampsia 59 kasus, pendarahan 40 kasus, infeksi 4 kasus, dan sebab lain 75 kasus. Kematin bayi dan balita mencapai 787 kasus, bayi dibawah usia 10 bulan 110 kasus (Dinkes Kota Bandar Lampung, 2017). Di kota Bandar Lampung terjadi 14 kasus kematian ibu dengan penyebab kematian masih seputar eklamsia 3 kasus, perdarahan 1 kasus, infeksi 3 kasus dan sebab lain 7 kasus (Dinkes Kota Bandar Lampung, 2018).

Data kejadian preeklamsia di Bandar Lampung, dengan membandingkan 3 Puskesmas yang memiliki angka kejadian preeklamsia tertinggi, yaitu Puskesmas Korpri sebanyak 9 (11,39\%) kejadian dari 79 ibu hamil, Puskesmas Sukaraja 7 $(10,60 \%)$ kejadian dari 66 ibu hamil, dan Puskesmas Pasar Simpur $7(11,11 \%)$ kejadian dari 63 ibu hamil (Data Dinkes Kota Bandar Lampung, 2019).

Sejalan dengan penelitian yang dilakukan oleh Sri Minarti, Arthati Eka Suryandari dan Misrina retnowati (2013) yang berjudul "Hubungan penambahan berat badan dengan kejadian preeklamsi pada ibu hamil di RSUD Prof. Dr. Margono Soekardjo purwokerto tahun 2011" yang menyimpulkan bahwa ada hubungan antara 
penambahan berat badan dengan kejadian preeklamsi pada ibu hamil $(p=0,004)$ (Sri Minarti, 2013).

Berdasarkan hasil prasurvey di Puskesmas Korpri Kota Bandar Lampung, terhadap 10 ibu hamil, $7(70 \%)$ diantaranya mengalami peningkatan berat badan setiap 3 bulannya sekitar $7-12 \mathrm{Kg}$, sedangkan $3(30 \%)$ orang lainnya hanya mengalami peningkatan berat badan antara $6-9 \mathrm{Kg}$.

\section{METODE PENELITIAN}

Jenis penelitian menggunakan kuantitatif, dengan rancangan penelitian survey analitik, dan pendekatan cross sectional, populasi dan sampel adalah ibu hamil di Puskesmas Korpri tahun 2019, teknik sampling simpel random sampling. Penelitian akan dilakukan pada tanggal 21-25 Agustus Tahun 2020.

\section{HASIL}

Karakteristik Responden

Tabel 1.

Karakteristik Responden Di Wilayah Kerja Puskesmas korpri Kota Bandar Lampung Tahun 2019

\begin{tabular}{lcc}
\hline \multicolumn{1}{c}{ Karakteristik } & Frekuensi & Persentase \\
\hline Usia & & \\
$\leq 20$ dan $\geq 30$ & 35 & 39,8 \\
Tahun & 53 & 60,2 \\
20-30 Tahun & & \\
$\begin{array}{l}\text { Pendidikan } \\
\text { Rendah }\end{array}$ & 21 & 30,7 \\
Menengah & 48 & 54,5 \\
Tinggi & 13 & 14,8 \\
Pekerjaan & & \\
Bekerja & 41 & 46,6 \\
Tidak Bekerja & 47 & 53,4 \\
Paritas & & \\
Primipara & 20 & 22,7 \\
Multipara & 56 & 63,6 \\
Grandemulti & 12 & 13,6 \\
\hline \multicolumn{1}{c}{ Total } & 88 & 100 \\
\hline
\end{tabular}

Berdasarkan tabel 1 diatas dapat diketahui karakteristik responden berdasarkan usia terbanyak adalah usia 20-35 tahun sebanyak 53 responden $(60,2 \%)$, berdasarkan pendidikan terbanyak adalah pendidikan menengah sebanyak 48 responden $(54,5 \%)$, pekerjaan terbanyak IRT/ tidak bekerja sebanyak 47 responden $(53,4 \%)$ dan berdasarkan paritas terbanyak adalah multipara sebanyak 56 responden $(63,6 \%)$.

\section{Analisa Univariat}

Tabel 2.

Distribusi Frekuensi Pertambahan Berat Badan Ibu Hamil Di Wilayah Kerja Puskesmas Korpri Kota Bandar Lampung Tahun 2019

\begin{tabular}{lcc}
\hline Pertambahan BB & Jumlah & Persentase \\
\hline Normal & 61 & 69,3 \\
Tidak Normal & 27 & 30,7 \\
\hline \multicolumn{1}{c}{ Total } & 88 & 100 \\
\hline
\end{tabular}

Dari tabel 2 diatas dapat dilihat distribusi frekuensi pertambahan berat badan dari 88 ibu hamil, dengan kategori berat badan normal 61 responden $(69,3 \%)$ dan kategori tidak normal sebanyak 27 responden $(30,7 \%)$

Tabel 3.

Distribusi Frekuensi Angka Kejadian

Preeklamsia Di Wilayah Kerja Puskesmas Korpri Kota Bandar Lampung Tahun 2019

\begin{tabular}{ccc}
\hline Preeklamsia & Jumlah & Persentase \\
\hline Tidak Preeklamsia & 60 & 68,2 \\
Preeklamsia & 28 & 31,8 \\
\hline Total & 88 & 100 \\
\hline
\end{tabular}

Dari tabel 3 diatas dapat dilihat distribusi frekuensi kejadian preeklamsia dari 88 ibu hamil, dengan kategori tidak mengalami preeklamsia 60 responden $(68,2 \%)$ dan kategori preeklamsia sebanyak 28 responden $(31,8 \%)$.

\section{Analisa Bivariat}

Tabel 4.

Hubungan Pertambahan Berat Badan Ibu Hamil Dengan Angka Kejadian Preeklamsia Di Wilayah Kerja Puskesmas Korpri Kota Bandar Lampung Tahun 2019

\begin{tabular}{|c|c|c|c|c|c|c|c|c|}
\hline \multirow{3}{*}{ Pertambahan BB } & \multicolumn{4}{|c|}{ Preeklamsia } & \multirow{2}{*}{\multicolumn{2}{|c|}{ Total }} & \multirow{3}{*}{ OR } & \multirow{3}{*}{$P$-Value } \\
\hline & \multicolumn{2}{|c|}{ Tidak } & \multicolumn{2}{|c|}{ Preeklamsia } & & & & \\
\hline & $\mathbf{N}$ & $\%$ & $\mathrm{~N}$ & $\%$ & $\mathrm{~N}$ & $\%$ & & \\
\hline Normal & 51 & 58,0 & 10 & 11,4 & 61 & 69,3 & 10,200 & 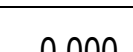 \\
\hline Tidak Normal & 9 & 10,2 & 18 & 20,5 & 27 & 30,7 & $(3,574-29,109)$ & 0.000 \\
\hline Total & 60 & 68,2 & 28 & 31,8 & 88 & 100,0 & & \\
\hline
\end{tabular}




\section{JKM (Jurnal Kebidanan Malahayati),Vol 7,No.2.April 2021, ISSN (Print) 2476-8944 ISSN (Online) 2579-762X, Hal 324-331}

Pada tabel 4 dapat dilihat responden dengan pertambahan BB normal sebanyak 61 responden $(69,3 \%)$ dan tidak preeklamsia sebanyak 51 responden $(58,0 \%)$ dan mengalami preeklamsia sebanyak 10 responden $(11,4 \%)$. Sedangkan pertambahan BB tidak normal 27 responden $(30,7 \%)$ dan tidak mengalami preeklamsia sebayak 9 responden $(10,2 \%)$ dan mengalami preeklamsia sebanyak 18 responden $(20,5 \%)$.

Hasil uji statistik menggunakan uji chi square didapat nilai $p$-value $=0.000(<0.05)$ yang artinya terdapat hubungan pertamahan berat badan ibu hamil dengan angka kejadian preeklamsia di Wilayah Kerja Puskesmas Korpri Kota Bandar Lampung Tahun 2019, dengan OR=10,200 yang artinya responden yang memiliki BB tidak normal akan 10 kali beresiko mengalami preeklamsia.

\section{PEMBAHASAN}

\section{Analisa Univariat}

Distribusi Frekuensi Pertambahan Berat Badan lbu Hamil Di Wilayah Kerja Puskesmas Korpri Kota Bandar Lampung Tahun 2019

Dari tabel 2 diatas dapat dilihat distribusi frekuensi pertambahan berat badan dari 88 ibu hamil, dengan kategori berat badan normal 61 responden $(69,3 \%)$ dan kategori tidak normal sebanyak 27 responden $(30,7 \%)$

Sejalan dengan teori yang dikemukakan oleh Magfiroh., dkk (2013)Pertambahan berat badan ibu hamil tidak hanya dipengaruhi oleh perubahan fisiologis ibu, tetapi juga dipengaruhi oleh karakteristik lain dan faktor biologis (metabolisme plasenta). Fungsi plasenta adalah sebagai organ endokrin dan zat perantara ibu dan janin. Perubahan homeostatis dapat merubah struktur dan fungsi plasenta yang berdampak terhadap kondisi pertumbuhan janin. Plasenta dapat mempengaruhi sistem metabolisme ibu karena adanya perubahan hormon insulin dan sistem peradangan, sehingga berakibat pada pertambahan berat badan ibu hamil.

Menurut peneliti pertambahan berat badan selama kehamilan sangat beragam dan dapat dipengaruhi oleh beberapa faktor. Pertambahan berat badan didistribusikan antara janin, plasenta, membran, cairan amnion, dan perkembangan fisiologis organ-organ maternal, mis, uterus dan payudara (deposisi darah dan lemak sebagai persiapan untuk laktasi). Sebagian besar wanita sehat di inggris memperoleh pertambahan berat badan antara 11 dan $16 \mathrm{~kg}$, meskipun ibu muda dan primigravida biasanya memperoleh pertambahan berat badan yang lebih dari ibu yang berusia lebih tua dan multigravida, seajalan dengan pendapat yang dikemukakan oleh Cunningham F. G (2016)
Kejadian peningkatan BB pada ibu hamil yang tidak terkontrol disebabkan karena ibu kurang informasi tentang bagaimana menjaga berat badan normal, pola makan, olahraga, serta diit rendah garam pada saat kehamilan. Berat badan berlebih memberikan risiko kehamilan yang tinggi yaitu diabetes gestasional, preeklamsia, kehamilan pascamatur, bedah caesar darurat, bedah caesar elektif, perdarahan pascapartum, infeksi panggul, infeksi saluran kemih, infeksi luka, makrosomia, lahir mati.(Hidayati,2006)

Peningkatan berat badan selama masa kehamilan terjadi karena adanya pertumbuhan janin, plasenta dan perubahan metabolik tubuh dari ibu. Namun perlu diketahui bahwa peningkatan berat badan ibu hamil sangat dipengaruhi oleh status gizi ibu, baik status gizi ibu sebelum hamil maupun selama masa kehamilan. Status gizi ibu yang baik sebelum hamil dapat menggambarkan ketersediaan cadangan zat gizi dalam tubuh ibu yang siap untuk mendukung pertumbuhan janin selama masa kehamilan. Selain itu, status gizi ibu hamil juga dipengaruhi oleh konsumsi zat gizi dan energi sesuai dengan kebutuhan ibu selama masa kehamilan (Waryana, 2010; Saimin, 2018).

Distribusi Frekuensi Angka Kejadian Preeklamsia Di Wilayah Kerja Puskesmas Korpri Kota Bandar Lampung Tahun 2019

Dari tabel 4.3 diatas dapat dilihat distribusi frekuensi kejadian preeklamsia dari 88 ibu hamil, dengan kategori tidak mengalami preeklamsia 60 responden $(68,2 \%)$ dan kategori preeklamsia sebanyak 28 responden $(31,8 \%)$.

Sejalan dengan teori yang dikemukakan oleh Wibowo, et al (2015)Preeklampsia merupakan kondisi spesifik pada kehamilan yang ditandai dengan adanya disfungsi plasenta dan respon maternal terhadap adanya inflamasi sistemik dengan aktivasi endotel dan koagulasi. Secara teoritik urutan gejala-gejala yang timbul pada preeklampsia ialah edema, hipertensi, dan terakhir proteinuria, bila gejala tersebut timbul tidak sesuai urutan diatas, berarti dianggap bukan preeklampsia.

Menurut peneliti preeklamsia adalah kondisi khusus masa kehamilan dimana terjadi hipertensi dan proteinuria setelah usia kehamilan 20 minggu pada ibu yang tadinya mempunyai tekanan darah normal. Preeklamsia merupakan penyulit kehamilan yang akut dan dapat terjadi ante, intra, dan postpartum. Edema, hipertensi, dan proteinuria adalah gejala yang timbul saat ibu hamil terkena preeklampsia.. Penelitian Sa'adah 2013 Analisis data dengan menggunakan uji Chi-Square menunjukkan hubungan yang bermakna antara 
pertambahan berat badan ibu hamil dan preeklampsia $(p=0,001)$. Dan dengan uji regresi linier didapatkan hasil yang bermakna antara pertambahan berat badan dengan preeklampsia $(p=0,002)$. Sedangkan didapatkan hasil yang tidak bermakna antara graviditas dengan preeklampsia $(p=0,129)$ dan antara usia dengan preeklampsia $(p=0,513)$.

Preeklamsia ditegakkan dengan tekanan
darah sekurang-kurangnya $140 / 90 \quad \mathrm{mmHg}$, dilakukan di lengan yang sama dengan jarak 15 menit sebanyak dua kali. (Handayani, 2019). Diagnosis preeklamsia kebanyakan ditegakkan dengan adanya protein urin, tetapi jika protein urine tidak terlihat, hal ini bukan berarti ibu sudah bebas dari preeclampsia. Tenaga kesehatan harus teliti apabila ada salah satu gangguan yang lain yang dapat digunakkan untuk menegakkan diagnose preeclampsia, misalnya trombositopenia: trombosit $<100.000$ /mikroliter, gangguan ginjal: kreatinin serum $>1,1 \mathrm{mg} / \mathrm{dL}$ atau ditemukan peningkatan kadar kreatinin serum pada kondisi dimana tidak ada kelainan ginjal lainnya, gangguan liver: peningkatan konsentrasi transaminase 2 kali normal dan atau adanya nyeri di daerah epigastrik/regio kanan atas abdomen, edema paru, didapatkan gejala neurologis: stroke, nyeri kepala, gangguan visus, gangguan pertumbuhan janin yang menjadi tanda gangguan sirkulasi uteroplasenta: Oligohidramnion, Fetal Growth Restriction (FGR) atau didapatkan adanya absent or reversed end diastolic velocity (ARDV) (PNPKI, 2016).

\section{Analisa Bivariat}

Hubungan Pertamahan Berat Badan Ibu Hamil Dengan Angka Kejadian Preeklamsia Di Wilayah Kerja Puskesmas Korpri Kota Bandar Lampung Tahun 2019

Hasil uji statistik menggunakan uji chi square didapat nilai $p$-value $=0.000(<0.05)$ yang artinya terdapat hubungan pertamahan berat badan ibu hamil dengan angka kejadian preeklamsia di Wilayah Kerja Puskesmas Korpri Kota Bandar Lampung Tahun 2019, dengan $O R=10,200$ yang artinya responden yang memiliki $\mathrm{BB}$ tidak normal akan 10 kali beresiko mengalami preeklamsia.

Sejalan dengan teori yang dikemukakan oleh Prawirohardjo (2014) Faktor risiko yang dapat mempengaruhi terjadinya hipertensi dalam kehamilan yaitu primigravida, primipaternitas, mola hidatidosa, diabetes melitus, kehamilan multipel, hidrops fetalis, bayi besar, umur yang ekstrim, riwayat keluarga ada yang pernah mengalami preeklamsia atau eklamsia, penyakit ginjal atau memang sudah mengalami hipertensi sebelum hamil, dan obesitas.

Karakteristik responden berdasarkan usia terbanyak adalah usia 20-35 tahun sebanyak 53 responden $(60,2 \%)$, Banyaknya preeklampsia yang terjadi pada rentang usia sehat dikarenakan proses kehamilan dan persalinan paling banyak terjadi pada usia produktif 20-35 tahun. Penelitian Khuzaiyah,2016 juga menunjukkan bahwa rata-rata pasien preeklampsia yang meninggal ada pada rentang usia 20-39 tahun, dengan rata-rata usia 28,2 tahun. Namun demikian, adanya data yang menunjukkan bahwa hampir separuh responden preeklampsia berusia resiko tinggi juga harus diperhatikan. Usia ibu berkaitan erat dengan sistem kekebalan tubuh, fungsi sel, serta berkaitan dengan kemampuan ibu dalam memberikan nutrisi dan oksigenasi kepada janin yang dikandung. Sebagian masalah kesehatan adalah berkaitan dengan usia. Tekanan darah tinggi dan beberapa bentuk diabetes berkaitan dengan usia. Pada usia $>35$ tahun juga seorang wanita mempunyai kesempatan $5 \%$ melahirkan bayi dengan kelainan kromosom.

Berdasarkan pendidikan terbanyak adalah pendidikan menengah sebanyak 48 responden $(54,5 \%)$, Pendidikan berkaitan dengan daya akses dan daya tangkap seseorang terhadap informasi kesahatan. Pendidikan juga berkaitan dengan kesadaran seseorang akan pentingnya perilaku hidup sehat. Tingkat pendidikan seseorang mempengaruhi bagaimana seorang mengambil keputusan atas masalah kesehatan yang dialaminya. Semakin rendah pendidikan ibu maka akan semakin sedikit keinginan memanfaatkan pelayanan kesehatan (Rukmini, 2005). ibu dengan pendidikan tinggi dan yang bekerja di sektor formal mempunyai akses yang lebih baik terhadap informasi tentang kesehatan, lebih aktif menentukan sikap dan lebih mandiri mandiri mengambil tindakan perawatan (Simamora, 2009).

Pekerjaan terbanyak IRT/ tidak bekerja sebanyak 47 responden $(53,4 \%)$ dan berdasarkan paritas terbanyak adalah multipara sebanyak 56 responden $(63,6 \%)$.

Sedangkan pertambahan BB tidak normal 27 responden $(30,7 \%)$ dan tidak mengalami preeklamsia sebayak 9 responden $(10,2 \%)$ dikarenakan ibu selalu menjaga kesehatan, mengurangi konsumsi makanan yang memicu preeklamsia. Indeks Massa Tubuh (IMT) kategori underweight pada pasien preeclampsia dan ibu hamil yang tidak preeclampsia ditemukan dengan proporsi sama pada penelitian ini, yaitu sebanyak $2,2 \%$. Wanita underweight lebih berisiko mengalami 


\section{JKM (Jurnal Kebidanan Malahayati),Vol 7,No.2.April 2021, ISSN (Print) 2476-8944 ISSN (Online) 2579-762X, Hal 324-331}

preeklampsia dibandingkan dengan yang memiliki berat badan normal. Hal ini dikaitkan dengan adanya anemia berat, serta defisiensi mikronutrien berupa kalsium dan zinc, yang diduga sebagai pemicu terjadinya preeklampsia (Andriani, 2016).

Pada penelitian ini tidak ada perbedaan proporsi underweight pada ibu hamil preeklampsia dan tidak preeklampsia, kemungkinan dissebabkan underweight bukan merupakan penyebab langsung terjadinya preeklampsia. Ibu hamil dengan IMT kategori underweight lebih berisiko mengalami preeklampsia jika telah terdapat anemia berat atau defisiensi mikronutrien yang dapat menyebabkan terjadinya preeklampsia melalui mekanis medis fungsi endotel yang dipicu oleh adanya reaksi stress oksidatif. Pertambahan berat badan berlebih terjadi karena organ-organ yang ada didalam tubuh tertutup oleh lemak sehingga menyebabkan mningkatnya teknanan darah selama kehamilan. Preeklampsia/eklampsiadidefin isikan adalah timbulnya hipertensi disertai proteinuria dan edema akhibat kehamilan setelah usia 20 minggu/segera setelah persalinan. Sedangkan etiologi dari preeklampsia/eklampsia belum diketahui secara pasti, namun faktor-faktor predisposisi dari preeklampsia yaitu usia, paritas, status social ekonomi, predisposisi genetik, komplikasi obstetrik dan kondisi medis yang sudah ada sebelumnya (JNPK-KR, 2008).

Menurut peneliti usia kurang dari 20 dan kirang dari 30 tahun sebnyk 35 responden $(39,8 \%)$, usia 20-35 tahun sebanyak 53 responden $(60,2 \%)$, berdasarkan pendidikan rendah 21 responden $(30,7 \%)$, pendidikan menengah 45 responden $(54,5 \%)$, pendidikan tinggi 13 responden $(14,8 \%)$, berdasarkn pekerjaan, bekerj 41 responden $(46,6 \%)$, tidak bekerj 47 responden $(53,4 \%)$, berdasarkn paritas, primpara 20 responden $(22,7 \%)$, multipara 56 responden $(63,6 \%)$, grandemulti 12 reponden $(13,6 \%)$.

Dampak yang dapat ditimbulkan dari preeklampsia pada ibu yaitu kelahiran prematur, oliguria, kematian, sedangkan dampak pada bayi yaitu pertumbuhan janin terhambat, oligohidramion, dapat pula meningkatkan morbiditas dan mortalitas. besitas disebapkan oleh banyak faktor seperti fakor genetik, gangguan metabolik dan konsumsi makanan yang berlebihan, semakin gemuk seseorang semakin banyak pula darah yang terdapat didalam tubuh yang berarti semakin berat fungsi pemompa jantung. Sehingga dapat mengakibatkan terjadinya preeklampsia

\section{SIMPULAN}

Dari penelitian yang berjudul hubungan pertamahan berat badan ibu hamil dengan angka kejadian preeklamsia di Puskesmas Korpri Kota Bandar Lampung Tahun 2019dapat disimpulkan sebagai berikut :Pertambahan berat badan dari 88 ibu hamil, dengan kategori berat badan normal 61 responden $(69,3 \%)$. Kejadian preeklamsia dari 88 ibu hamil, dengan kategori tidak mengalami preeklamsia 60 responden $(68,2 \%)$. Hasil uji statistik menggunakan uji chi square didapat nilai $p$ value $=0.000(<0.05)$ yang artinya terdapat hubungan pertamahan berat badan ibu hamil dengan angka kejadian preeklamsia di Puskesmas Korpri Kota Bandar Lampung Tahun 2019

\section{SARAN}

Bagi Puskesmas Korpri Kota Bandar Lampung kepada tenaga kesehatan dapat memberikan memberikan edukasi kepada ibu hamil guna mendeteksi dini adanya preeklampsia dan memberikan pelayanan maksimal kepada penderita preeklampsia guna mencegah terjadinya komplikasi. Bagi Responden kepada seluruh calon ibu disarankan untuk merencanakan hamil di usia produktif yaitu usia 20 - 35 tahun karena dalam rentang usia tersebut kerja organ reproduksi telah maksimal dan bila ibu merencanakan kehamilan berikutnya, ibu disarankan melakukan pemeriksaan kehamilan secara rutin untuk pengenalan dan pengelolaan risiko kehamilan sebelumnya sehingga diharapkan selama hamil ibu tidak menghadapi risiko berat. Bila ditemukan risiko berat, tidak disarankan untuk merencanakan kehamilan berikutnya. Selain itu, ibu juga harus menjaga berat badannya agar ideal dengan tinggi badannya, jika ibu hamil dengan berat badan yang berlebihan sebelum kehamilan, maka pertambahan yang dianjurkan harus lebih kecil dari pada ibu hamil dengan berat badan ideal. Bagi Peneliti Selanjutnya hasil penelitian ini diharapkan dapat dianalisis lebih lanjut terutama pada variabel indeks massa tubuh bisa ditambahkan dengan menganalisis pertambahan berat badan tiap trimester dari trimester awal sampai terakhir serta mengembangkan metode penelitian untuk mengetahui pengaruh penelitian terhadap masingmasing variabel faktor risiko lain yang berhubungan dengan kejadian preeklampsia yang menjadi permasalahan di masyarakat.

\section{DAFTAR PUSTAKA}

Adriani, Merryana. S. K. M., \& Kes, M. (2016). Pengantar gizi masyarakat. Prenada Media. 
Al-Herz, W., Bousfiha, A., Casanova, J. L., Chatila, T., Conley, M. E., Cunningham-Rundles, C., ... \& Klein, C. (2014). Primary immunodeficiency diseases: an update on the classification from the international union of immunological societies expert committee for primary immunodeficiency. Frontiers in immunology, 5, 162.

Andriani, C., Lipoeto, N. I., \& Utama, B. I. (2016). Hubungan Indeks Massa Tubuh dengan Kejadian Preeklam0psia di RSUP Dr. M. Djamil Padang. Jurnal Kesehatan Andalas, 5(1).

Andriyani (2016). Hubungan Indeks Massa Tubuh dengan Kejadian Preeklampsia di RSUP Dr. M. Djamil Padang.

Arisman, MB. (2010). Gizi Dalam Kehidupan. Jakarta : EGC.

Bellver dkk., (2009; Pramaningtyas, 2019) Hubungan Kenaikan Berat Badan Selama Hamil Dengan Kejadian Preeklamsia Di Rsudgambiran Kota Kediri. Politeknik Kesehatan Kemenkes Malang Prodi Kebidanan Kediri JI.Kh. Wachid Hasyim No.64b. Kediri

Bodnar, L. M., Himes, K. P., Abrams, B., Parisi, S. M., \& Hutcheon, J. A. (2018). Earlypregnancy weight gain and the risk of preeclampsia: A case-cohort study. Pregnancy hypertension, 14, 205-212.

Cunningham, D., Allum, W. H., Stenning, S. P., Thompson, J. N., Van de Velde, C. J., Nicolson, M., ... \& Smith, D. B. (2006). Perioperative chemotherapy versus surgery alone for resectable gastroesophageal cancer. New England Journal of Medicine, 355(1), 11-20.

Cunningham, F. G., Leveno, K. J., Bloom, S. L., Spong, C. Y., Dashe, J. S., Hoffman, B. L., ... \& Sheffield, J. S. (2016). Obstetricia de Williams. McGraw Hill Brasil.

Dinkes Bandar Lampung. (2019). Angka Kejadian Preeklamsia.

Dumais, C., Lengkong, R. A., \& Mewengkang, M. E. (2016). Hubungan obesitas pada kehamilan dengan preeklampsia. e-CliniC, 4(1).

Gorsek, A. K., \& Cunningham, M. M. (2014). A review of teachers' perceptions and training regarding school bullying. Pure insights, 3(1), 6.

Handayani, E., \& Rahmawati, A. (2019). FAKTORFAKTOR YANG MEMPENGARUHI KEJADIAN PREEKLAMPSIA DI RSUD
WATES KABUPATEN KULONPROGO TAHUN 2019 (Doctoral dissertation, Poltekkes Kemenkes Yogyakarta).

Hardinsyah, M. S., \& Supariasa, I. D. (2017). IImu gizi teori dan aplikasi. Jakarta: EGC.

Hidayati, N. F. (2006). KEJADIAN HIPERTENSI PADA IBU HAMIL TRIMESTER II DAN III (STUDI KASUS DI POLI HAMIL I RSU DR. SOETOMO SURABAYA) (Doctoral dissertation, UNIVERSITAS AIRLANGGA).

Jannah, Nurul. (2019). Buku Ajar Asuhan Kebidanan Kehamilan. Yogyakarta: Andi Ofset.

JNPK-KR, 2008 Asuhan Persalinan Normal: Jakarta: JHPIEGO

Kathlen., dkk (2011) Outdoor Play and Learning: Policy and Practice. International Journal of Education Policy and Leadership, November Maghfiroh, L. Pertambahan Berat Badan Ibu Hamil dan Kejadian Berat Bayi Lahir Rendah (BBLR) di Wilayah Kerja Puskesmas Pamulang Tahun 2013-2015.4, Volume 6: 8.

Kemenkes RI. (2019). Angka Kejadian Preeklamsia. Kemenkes RI. (2018). Angka Kejadian Preeklamsia.

Khuzaiyah, S., Anies, A., \& Wahyuni, S. (2016). Karakteristik Ibu Hamil Preeklampsia. Jurnal IImiah Kesehatan, 9(2), 97065.

Maulana. (2012). Panduan Lengkap Kehamilan. Kata hati: Yogyakarta.

Minarti, S., Suryandari, A. E., \& Retnowati, M. (2011). HUBUNGAN PENAMBAHAN BERAT BADAN DENGAN KEJADIAN PRE EKLAMPSI PADA IBU HAMIL DI RSUD PROF. Dr. MARGONO SOEKARDJO PURWOKERTO TAHUN 2011. Bidan Prada: Jurnal Publikasi Kebidanan Akbid YLPP Purwokerto, 4(01).

Mochtar, R. (2013). Sinopsis Obstetri Fisiologi dan Patologi edisi 2. EGC : Jakarta.

Notoatmodjo, S. (2018). Metode Penelitian Kesehatan. Jakarta: Rineka Cipta.

Pratamaningtyas, S., Kristianti, S., \& Nafiah, S. N. I. (2019). HUBUNGAN KENAIKAN BERAT BADAN SELAMA HAMIL DENGAN KEJADIAN PREEKLAMSIA DI RSUDGAMBIRAN KOTA KEDIRI. JURNAL KEBIDANAN KESTRA (JKK), 2(1), 95-102.

Prawirohardjo, S. (2014). Ilmu Kebidanan Sarwono Prawirohardjo. Jakarta: PT. Bina Pustaka Sarwono Prawirohardjo. 
JKM (Jurnal Kebidanan Malahayati),Vol 7,No.2.April 2021,

ISSN (Print) 2476-8944 ISSN (Online) 2579-762X, Hal 324-331

Sa'adah, N. (2013). Hubungan Antara Pertambahan Berat Badan Ibu Hamil dengan Angka Kejadian Preeklampsia di RSUD Dr. Moewardi Surakarta (Doctoral dissertation, Universitas Muhammadiyah Surakarta).

Saimin, J., Faisal, M., Asmarani, A., \& Wicaksono,

S. (2019). Peningkatan berat badan ibu hamil mempengaruhi berat badan lahir bayi di daerah pesisir. Preventif Journal, 2(2).

Simamora, N. R. H., \& Kep, M. (2009). Buku ajar pendidikan dalam keperawatan. EGC. 